\title{
THE PROTECTIVE ROLE OF TANNIC ACID AGAINST POSSIBLE HEPATO-NEPHROTOXICITY INDUCED BY SILVER NANOPARTICLES ON MALE RATS
}

\author{
Mosa F Israa, ${ }^{1 *}$ Youssef Mokhtar, ${ }^{2}$ Shalaby Thanaa, ${ }^{3}$ Mosa F Osama ${ }^{4}$ \\ ${ }^{1 *}$ Department of Environmental Studies, Institute of Graduate Studies and Research, \\ Alexandria University, Alexandria, Egypt \\ ${ }^{2}$ Department of Environmental Studies, Institute of Graduate Studies and Research, \\ Alexandria University, Alexandria, Egypt \\ ${ }^{3}$ Department of Biophysics, Medical Research Institute, Alexandria University Alexandria, Egypt \\ ${ }^{4}$ Department of Public Health, Health Sciences College at Leith, \\ Umm Al Qura University, Al-Leith, Makkah, Saudi Arabia
}

Primljen/Received 22. 05. 2019. god.

Abstract: Silver nanoparticles (AgNPs) are being used extensively for biomedical purposes regarding to their broad antimicrobial activity, however their toxicity has been addressed in only few studies. In the present study, we aimed to prepare and characterize AgNPs, investigate their adverse effect on liver and kidney functions, and also elucidate the hepato-nephro protective ability of tannic acid in male rats. The obtained results showed that AgNPs caused oxidative stress throughout the induction of thiobarbituric acid-reactive substances (TBARS) and the reduction of the activities of antioxidant enzymes (GST, SOD, CAT, GPx) and the levels of glutathione. Hepatic markers enzymes (AST, ALT, ALP, ACP, LDH and GGT), total bilirubin, urea, creatinine and lipid profile were increased, while hematological parameters were decreased. Histopathological investigations indicated marked degeneration of hepatocytes, endothelial cells of renal which with its role has confirmed the hepatotoxicity and nephrotoxicity induced by AgNPs. The presence of tannic acid along with AgNPs showed obvious improvements in the injured liver and kidney tissues. The protective effect of tannic acid against the toxicity of AgNPs might be due to its antioxidant properties and scavenging abilities against active free radicals.

Key words: Silver nanoparticles, Tannic acid, nanotoxicology, Hepatotoxicity, renal damage, Reactive oxygen species, DNA oxidation, oxidative stress, histopathological architecture.
Prihvaćen/Accepted 25. 07. 2019. god.

\section{INTRODUCTION}

During the last decade, a rising research has been done on metal nanoparticulates due to their excellent catalytic, optical, electrical, magnetic, antimicrobial and other physical and chemical characteristics; those are completely different from their bulk size. Silver nanoparticles (AgNPs) are believed to be one of the most substantial types of metal nano-materials which have been used increasingly in medical field, because of their strong bacteriostatic (1), antiviral (2) and fungicidal effects (3). AgNPs are widely used in dietary supplementations, for dental hygiene, wound dressing and also in medical devices and implants (4). Moreover, silver nanoparticles have been used in a wide range in consumer products especially air and water filters due to their antiseptic properties, towels, clothes, paints and cleansers for surface cleansing, as well as many applications in biotechnology and life sciences (5). They have also been used for the treatment of many diseases such as breast cancer, leukemia and different carcinomas (6). Regular consumption and direct contact with products like medications and food containing silver nanoparticles represent a sustainable source of AgNPs which when emitted to the environment might produce a substantial contamination hazard (7) and a prospective risk to human health (8).

Silver nanoparticles antibacterial properties influenced in many applications in several areas such as food, health and electronics. Its increased usage contri- 
butes to its consumer exposure which with its role rise a variety of questions in terms of safety risk. However, AgNPs effects on humans is still under inspection. In the literature, most studies on AgNPs are in vitro, intravenous, inhalation, intraperitoneally and subcutaneous (9). It has been elucidated that AgNPs induced cytotoxicity in vitro though free radical generation (10).

Silver Nanoparticles can be taken in the gastrointestinal (GI) barrier, enter the circulation system, and translocation in different organs i.e. (Liver, brain, kidney, lung, spleen and small intestine) (11). The mechanism of toxicity of silver nanoparticles is related to reactive oxygen species (ROS) generation and oxidative stress elevation resulting in lipid peroxidation, apoptosis, damage to protein and DNA, membrane leakage and kidney dysfunction (12). AgNPs release silver ions in suspension, because of its surface charge, particle size or coating (11). Moreover, ions released from silver nanoparticles could penetrate cells and spread through biological barriers to achieve equilibrium concentration (13).

Reactive oxygen species cause numerous toxic effects which are associated with various pathogens, including neurodegeneration, carcinogenesis, atherosclerosis, aging and diabetes. However, it is well known that protracted exposure to ROS in high concentrations leads to several disorders $(14,15)$. Therefore, an increasing requirement for antioxidants has been made in order to identify natural sources for vigorous antioxidant polyphenols and phytochemicals. Tannic acid is a hydrolysable natural polyphenol that has been extensively found in a range of plants such as grapes, oak, and green tea (16). It has been approved safe for direct usage in pharmaceutical products by the FDA (17). Tannic acid has been used as a medication for the treatment of vasodilation, intestinal lesions and reducing inflammation because of its antimicrobial activity (18), inhibition of apoptosis of tumor cells with antigenic and antimutagenic activity (19), decreasing pain (20), and hypoglycemic effects regulation (21). Phenolic acid antioxidant activity is due to several different mechanisms, such as scavenging free-radical, donating hydrogen atoms, quenching singlet oxygen, chelating metal ion, activating antioxidant enzymes and acting as radical'ssubstrate such as hydroxyl or superoxide. The main defense mechanism of phenolic acid is torevoke ROS generation and thus avoid oxidative damage formation (15).

Given the potential oxidative effects of AgNPs, we aimed at the present study to investigate the possible toxic effect of AgNPs following 77 days repeated i.p. exposure on some biomarkers of oxidative stress, histopathological alterations, biochemical and hematological parameters in rat's liver and kidney. Also, study the mitigation effect of tannic acid against AgNPs-induced toxicity.

\section{MATERIAL AND METHODS}

\section{Chemicals}

Silver nitrate $\left(\mathrm{AgNo}_{3}\right)$, trisodium citrate dehydrates $\left(\mathrm{C}_{6} \mathrm{H}_{5} \mathrm{O} 7 \mathrm{Na}_{3} .2 \mathrm{H}_{2} \mathrm{O}, 99.99 \%\right)$ and tannic acid $\left(\mathrm{H}_{76} \mathrm{C}_{52} \mathrm{O}_{46}\right.$, MW 1701.20) were purchased from Sigma Aldrich (St. Louis, MO, USA). All other chemicals used in the experiment were of analytical grade or highest grade available.

\section{Synthesis of silver nanoparticles}

Silver nanoparticles were prepared by chemical reduction method according to Fang et al. (22), by aqueous $\mathrm{AgNO}_{3}$ reducing with sodium citrate at boiling temperature. In typical procedure, a $50 \mathrm{ml}$ of $1 \mathrm{mM}$ $\mathrm{AgNO}_{3}$ was heated till boiling. To this solution, $5 \mathrm{ml}$ of $1 \% \mathrm{Na}_{3} \mathrm{C}_{6} \mathrm{H}_{5} \mathrm{O}_{7}$ was added drop by drop. The solution was heated at boiling point under continuous stirring. The reaction was allowed to take place until the color changed to greenish yellow. The solution was then cooled to room temperature.

\section{Characterization of silver nanoparticles}

Nanoparticles size and morphology were analyzed with a transmission electron microscope (TEM; JEOL JSM 100CX, Japan), a drop of synthesized silver nanoparticles solution was placed on the carbon coated copper $(\mathrm{C} / \mathrm{Cu})$ grids and kept overnight under vacuum desiccation. The carbon coated copper grids were then loaded onto a specimen holder. TEM micrographs of the sample were taken by TEM operated at $80 \mathrm{kV}$ accelerating voltage. Silver colloids optical absorption features in the UV-visible range of 300-700 nm wave length were measured using UV-VIS Spectrophotometer (Jenway 6405, UK). The samples for X-ray diffraction (XRD) analysis were made to study the crystalline nature of the prepared AgNPs by (Shimadzu, XRD-7000, Maxima, Japan) operated at $30 \mathrm{kV}$ and $30 \mathrm{~mA}$ current with $\mathrm{CuK} \alpha$ radiation and scan between 10 to $79.9^{\circ}(2 \theta)$ with $0.2^{\circ}$ step intervals

The particle size of silver nanoparticle was calculated from the width of the XRD peaks, using the Debye-Scherrer formula:

$$
\mathrm{D}=0.94 \lambda / \hat{\mathrm{a}} \operatorname{Cos} \text { è } \theta
$$

Where $\mathrm{D}$ is the average crystallite domain size perpendicular to the reflecting planes, $\lambda$ is the wavelength of X-ray, $\beta$ â is the angular full width at half maximum (FWHM), and $\theta$ is the angle of diffraction (Bragg's angle). 
FT-IR spectrum was obtained using FT-IR spectrophotometer (Shimazdu IR Prestige-21). The sample was mixed uniformly with potassium bromide at 1:100 (sample: $\mathrm{KBr}$ ) ratio respectively and incubated at $110^{\circ} \mathrm{C}$ overnight. After that, the mixture was cooled down in desiccators. The $\mathrm{KBr}$ discs were prepared by compressing the powders (mixture of sample and $\mathrm{KBr}$ ) in a hydraulic press. The discs were scanned in the range of $400-4000 \mathrm{~cm}^{-1}$ to obtain FT-IR spectrum.

\section{Test chemicals and treatment}

Silver nanoparticles were suspended directly in deionized water and dispersed by ultrasonic vibration. The size of AgNPs (less than $100 \mathrm{~nm}$ ) was tested at a dose of $50 \mathrm{mg} / \mathrm{kg} \mathrm{BW} /$ day and was injected intraperitoneally (IP) every day for 77 consecutive days to male Wistar rats, this dose was chosen according to Sharmaet al. (23). On the other hand, the dose of tannic acid (100 $\mathrm{mg} / \mathrm{kg} \mathrm{BW} /$ day) was given orally for the same period of time and was chosen according to Di Meo et al. (14).

\section{Animals and experimental design}

This experiment followed the ethics criterion of the Animal Ethics Committee of the Institute of Graduate Studies and Research, Ethical Approval No.APGI-07/2015. Alexandria University (Alexandria, Egypt). The study was done on 40 adults male Wistar rats weighing $(200 \pm 22)$ g obtained from the Faculty of Medicine, Alexandria University, Egypt. Animals were housed in a comfortable environment kept on basal diet and tap water which were provided ad libitum. Animals were maintained in a controlled atmosphere, a temperature of $25 \pm 5^{\circ} \mathrm{C}$ and $50-70 \%$ humidity. They were monitored during the period of treatment. Food and water intake, and body weights were weekly recorded through the whole experimental period. After acclimation for 2 weeks; they were randomly divided into 4 equal groups and each cage housed a maximum of 5 rats. The first group was used as control; the second group was orally treated with tannic acid $(100 \mathrm{mg} / \mathrm{kg}$ $\mathrm{BW} /$ day). The third group was intraperitoneally (IP)treated with silver nanoparticles (50 mg/kg BW/day) and the forth group was treated with both silver nanoparticles and tannic acid. Rats were administered their respective doses of silver nanoparticles and tannic acid every day for 77 consecutive days.

\section{Blood samples collection and tissue preparations}

At the end of the $77^{\text {th }}$ day of the experimental period, animals were anaesthetized with diethyl ether and blood samples were rapidly taken from the rats' aorta after scarification then collected in test tubes containing heparin and placed on ice immediately. The collected blood was centrifuged at $860 \mathrm{xg}$ for $20 \mathrm{~min}$ for the separation of plasma. The plasma was kept at $-80^{\circ} \mathrm{C}$ until tested parameters analyses. Liver and kidney were removed, washed using saline solution and adhering fat and connective tissues were removed. Liver and kidney were minced and homogenized separately $(10 \%$, $\mathrm{w} / \mathrm{v})$, in ice-cold sucrose buffer $(0.25 \mathrm{M})$ in a Potter-Elvehjemhomogenizer. Homogenates were then centrifuged at $10,000 \mathrm{xg}$ for $20 \mathrm{~min}$ at $4{ }^{\circ} \mathrm{C}$, in order to pellet the cell debris and collect the supernatant, then stored at $-80^{\circ} \mathrm{C}$ for the tested parameters determination.

\section{Markers of oxidative stress and antioxidant parameters}

Lipid peroxidation index in kidney and liver homogenate was assayed as thiobarbituric acid-reactive substances (TBARS) which were measured at $532 \mathrm{~nm}$, using 2-thiobarbituric acid (2,6-dihydroxypyrimidine-2-thiol; TBA). TBARS levels were measured by the method of Tappel\&Zalkin (25). The activity of superoxide dismutase (SOD) was measured according to Mishra \&Fridovich (26). The assay procedure of SOD determination involves epinephrine inhibition of auto-oxidation in an alkaline medium $(\mathrm{pH}$ 10.2) to adrenochrome, which is inhibited by the presence of SOD. Epinephrine was added to the assay mixture, containing tissue supernatant and the change in coefficient extinction was followed at $480 \mathrm{~nm}$ in a Spectrophotometer. The glutathione peroxidase (GPx) activity was assayed by the method of Chiu et al. (27) in kidney and liver homogenate. The activity of Glutathione S-transferase (GST) was determined according to Habig et al. (28). The GST activity was measured in kidney and liver homogenate and p-nitrobenzyl chloride was used as substrate. The measure absorbance was detected at $310 \mathrm{~nm}$ using UV-Double Beam Spectrophotometer. The activity of catalase (CAT) was determined using the Luck method involving the hydrogen peroxide decomposition (29). The CAT activity was measured at $240 \mathrm{~nm}$ by calculation the rate of hydrogen peroxide degradation. The content of reduced glutathione (GSH) was determined and the method applied metaphosphoric acid for precipitation of protein and DTNB for color development and its density was measured at $412 \mathrm{~nm}$. GSH content was determined according to the method of Jollow et al. (30).

\section{Biochemical and hematological parameters}

Plasma total protein, albumin, urea, creatinine, and total bilirubin were measured with kits from Biosystems S.A (Costa Brava 30, Barcelona, Spain). The 
activities of plasma and liver aspartate transaminase, alanine transaminase, alkaline phosphatase, acid phosphatase, lactate dehydrogenase and gamma glutamyte transaminase (GGT) were measured with kits from Biosystems S.A (Costa Brava 30, Barcelona, Spain). HA-VET CLINDIAG was used to measure the following hematological parameters: Red Blood cells, hemoglobin, hematocrit, mean corpuscular volume, mean corpuscular hemoglobin, mean corpuscular hemoglobin concentration, white blood cells and platelets counts.

\section{Histological section preparation of liver and kidney}

Liver and kidney specimens obtained from rats were immediately fixed in $10 \%$ formalin, and treated with plain grade of alcohol and xylol, embedded in paraffin and sectioned at 4-6 $\mu \mathrm{m}$ thickness. The sections were stained with (H\&E) for studying the histopathological changes Drury et al. (31).

\section{Statistical analysis}

The results were reported as means $\pm \mathrm{SE}$, and statistical analysis for the previously studies parameters were performed following the general linear model (GLM) produced by SAS Institute (32). Duncan's New Multiple Range Test was used to test the significance of the differences between means [33]. Values of $p<$ 0.05 were supposed to be statistically significant.

\section{RESULTS}

\section{Preparation and characterization of silver nanoparticles}

UV-Vis spectroscopy is a method used to examine nanoparticles production based on their optical characteristic. Silver nanoparticles absorption band shows

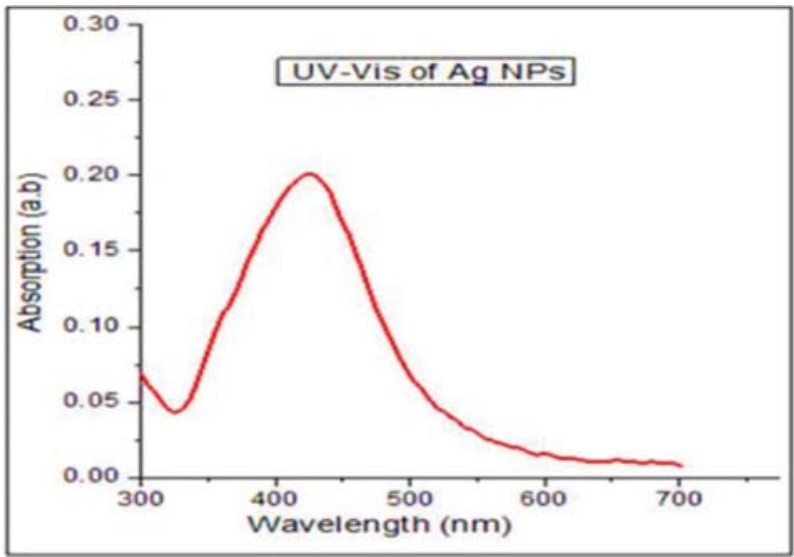

Figure 1: UV-Vis absorption spectrum of silver nanoparticles (AgNPs)
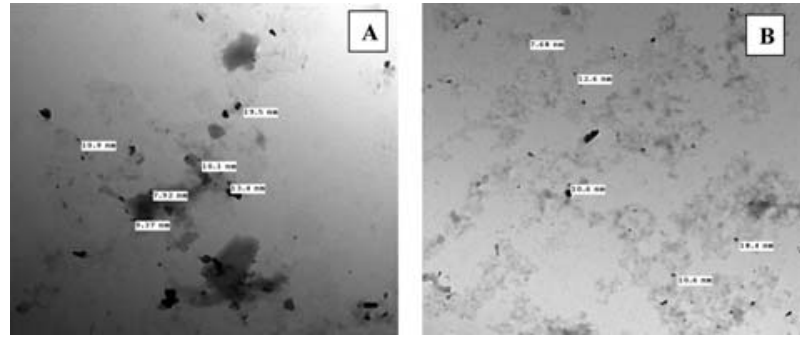

Figure 2: Transmission Electron Microscopy (TEM) image of $\operatorname{AgNPs}(A \& B)$

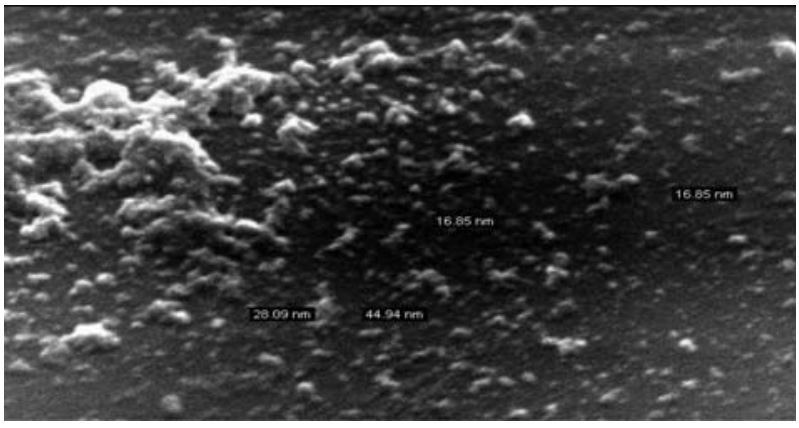

Figure 3: Scanning Electron Microscopy (SEM) of AgNPs

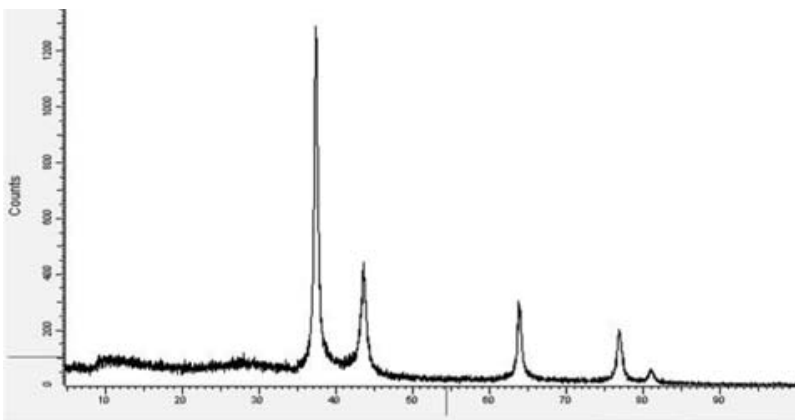

Figure 4: XRD pattern of silver nanoparticles

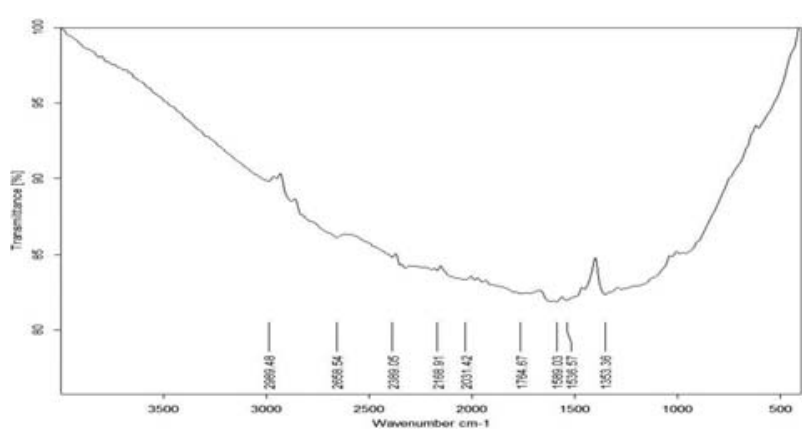

Figure 5: FTIR spectra of AgNPs

strong absorption at $425 \mathrm{~nm}$ (Figure 1). The typical Transmission Electron Microscopy (TEM) images of the synthesized AgNPs are presented in Figure 2 (A and $B$ ). It is observed that most of them were spherical in shape and homogeneously distributed (Figure 2 (A and B)). The Scanning Electron Microscopy (SEM) image of silver nanoparticles is shown in Figure 3. The morphology of AgNPs shown in Figure 4 confirms that AgNPs are spherical in shape in the range of $17-51 \mathrm{~nm}$. 
The peaks at $2 \theta=38.07^{\circ}, 44.18^{\circ}, 64.37^{\circ}$ and $77.29^{\circ}$ can be assigned to reflections from the $111,200,220$ and 311 planes respectively, of metallic silver in FCC phase. Figure 5 shows various peaks for the FT-IR spectrum recorded for AgNPs. The peak at $1599 \mathrm{~cm}^{-1}$ is very broad and strong, and can be assigned to the hydroxyl group, also a prominent and very sharp peak is observed at $1353 \mathrm{~cm}^{-1}$ due to the nitrate ions group.

\section{Markers of oxidative stress and antioxidant parameters}

The levels of thiobarbituric acid-reactive substances (TBARS) and reduced glutathione (GSH), and the activities of superoxide dismutase (SOD), glutathione peroxidase (GPx), glutathione S-transferase (GST) and catalase (CAT) were measured in liver and kidney of male rats treated daily for 77 days with tannic acid, AgNPs and their combination were presented in Table 1 and 2 and Figure 6 and 7. Data indicated that treat- ment with AgNPs alone significantly $(\mathrm{P}<0.05)$ decreased the activities of SOD, CAT, GST, GPx and the level of GSH, and increased the levels of TBARS in liver and kidney compared to control group. While, treatment with tannic acid alone significantly $(\mathrm{P}<0.05)$ increased the activities of SOD, CAT, GST, GPx and the levels of GSH, but decreased TBARS levels in liver and kidney. While, the presence of tannic acid along with AgNPs in the combination group minimized the toxic effect on all above parameters compared to AgNPs treated group.

\section{Biochemical parameters}

Table 3 and Figure 8 represented the mean values of the activities of alanine transaminase (ALT), aspartate transaminase (AST), acid phosphatase (ACP), alkaline phosphatase (ALP), gama-glutamyl transferase (GGT) and lactate dehydrogenase (LDH) in plasma and liver of male rats treated with tannic acid, AgNPs,

Table 1. Liver levels of thiobarbituric acid-reactive substances, glutathione, superoxide dismutase, glutathione peroxidase, glutathione S-transferase and catalase of male rats treated with tannic acid, silver nanoparticles (AgNPs)and their combination

\begin{tabular}{|l|c|c|c|c|}
\hline \multirow{2}{*}{\multicolumn{1}{c|}{ Parameter }} & \multicolumn{4}{c|}{ Experimental groups } \\
\cline { 2 - 5 } & Control & Tannic Acid & AgNPs & AgNPs+TA $^{*}$ \\
\hline TBARS (mg/ml protein) & $21.8 \pm 1.40^{\mathrm{c}}$ & $16.0 \pm 1.67^{\mathrm{d}}$ & $43.8 \pm 2.59^{\mathrm{a}}$ & $36.0 \pm 1.55^{\mathrm{b}}$ \\
\hline GSH (mU/mg protein) & $4.83 \pm 0.20^{\mathrm{b}}$ & $5.88 \pm 0.09^{\mathrm{a}}$ & $3.21 \pm 0.19^{\mathrm{d}}$ & $3.92 \pm 0.11^{\mathrm{c}}$ \\
\hline SOD (mU/mg protein) & $5.74 \pm 0.25^{\mathrm{b}}$ & $6.70 \pm 0.17^{\mathrm{a}}$ & $4.19 \pm 0.21^{\mathrm{d}}$ & $4.84 \pm 0.13^{\mathrm{c}}$ \\
\hline GPx (mU/mg protein) & $34.8 \pm 1.31^{\mathrm{b}}$ & $47.3 \pm 2.00^{\mathrm{a}}$ & $27.6 \pm 1.19^{\mathrm{d}}$ & $32.3 \pm 1.50^{\mathrm{bc}}$ \\
\hline GST (mU/mg protein) & $1.28 \pm 0.03^{\mathrm{b}}$ & $1.57 \pm 0.05^{\mathrm{a}}$ & $0.86 \pm 0.05^{\mathrm{d}}$ & $1.09 \pm 0.03^{\mathrm{c}}$ \\
\hline CAT (mU/mg protein) & $59.17 \pm 2.36^{\mathrm{b}}$ & $70.65 \pm 2.25^{\mathrm{a}}$ & $38.27 \pm 1.54^{\mathrm{d}}$ & $47.81 \pm 2.40^{\mathrm{c}}$ \\
\hline
\end{tabular}

* Mean values within a column not sharing a common superscript letter ( $\mathrm{a}, \mathrm{b}, \mathrm{c}$ ) were significantly different, $\mathrm{p}<0.05$.

* TBARS $=$ Thiobarbituric acid-reactivesubstances, $\mathrm{GSH}=$ Reduced glutathione concentration, $\mathrm{SOD}=$ Superoxide dismutase, $\mathrm{GPx}$ $=$ Glutathione peroxidase, GST $=$ Glutathione $\mathrm{S}$-transferase, $\mathrm{CAT}=$ Catalase .

Table 2. Kidneylevels of thiobarbituric acid-reactive substances, glutathione, superoxide dismutase, glutathione peroxidase, glutathione S-transferase and catalase of male rats treated with tannic acid, silver nanoparticles (AgNP) and their combination

\begin{tabular}{|l|c|c|c|c|}
\hline \multirow{2}{*}{\multicolumn{1}{c|}{ Parameter }} & \multicolumn{4}{c|}{ Experimental groups } \\
\cline { 2 - 5 } & Control & Tannic Acid & AgNPs & AgNPs+TA \\
\hline TBARS (mg/ml protein) & $27.67 \pm 1.36^{\mathrm{c}}$ & $22.17 \pm 1.92^{\mathrm{d}}$ & $43.83 \pm 1.99^{\mathrm{a}}$ & $36.00 \pm 1.79^{\mathrm{b}}$ \\
\hline GSH (mU/mg protein) & $5.41 \pm 0.33^{\mathrm{b}}$ & $6.00 \pm 0.37^{\mathrm{a}}$ & $3.77 \pm 0.17^{\mathrm{d}}$ & $4.63 \pm 0.12^{\mathrm{c}}$ \\
\hline SOD (mU/mg protein) & $6.93 \pm 0.30^{\mathrm{b}}$ & $8.02 \pm 0.19^{\mathrm{a}}$ & $3.61 \pm 0.20^{\mathrm{d}}$ & $5.46 \pm 0.28^{\mathrm{c}}$ \\
\hline GPx (mU/mg protein) & $58.01 \pm 2.43^{\mathrm{b}}$ & $68.49 \pm 2.95^{\mathrm{a}}$ & $27.07 \pm 1.34^{\mathrm{d}}$ & $40.50 \pm 0.67^{\mathrm{c}}$ \\
\hline GST (mU/mg protein) & $1.41 \pm 0.06^{\mathrm{b}}$ & $1.73 \pm 0.06^{\mathrm{a}}$ & $0.92 \pm 0.04^{\mathrm{d}}$ & $1.24 \pm 0.07^{\mathrm{c}}$ \\
\hline CAT (mU/mg protein) $^{*}$ & $57.02 \pm 2.22^{\mathrm{b}}$ & $71.26 \pm 1.97^{\mathrm{a}}$ & $31.12 \pm 1.71^{\mathrm{d}}$ & $47.23 \pm 1.85^{\mathrm{c}}$ \\
\hline
\end{tabular}

* Mean values within a column not sharing a common superscript letter ( $a, b, c)$ were significantly different, $\mathrm{p}<0.05$.

* TBARS $=$ Thiobarbituric acid-reactivesubstances, GSH = Reduced glutathione concentration, SOD = Superoxide dismutase, GPx

$=$ Glutathione peroxidase, GST $=$ Glutathione $\mathrm{S}$-transferase, $\mathrm{CAT}=$ Catalase . 

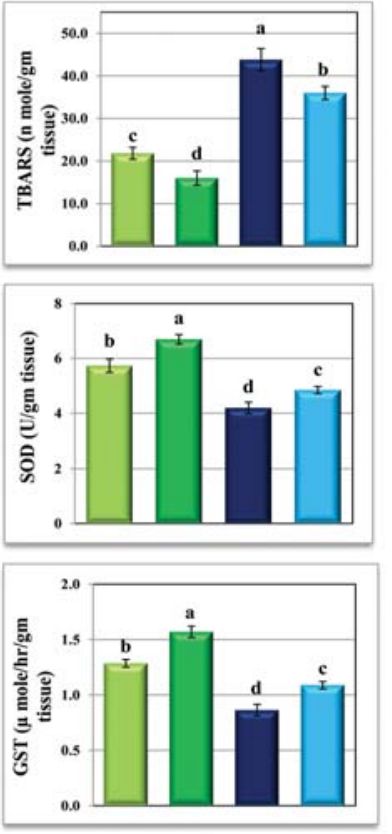

\section{(1)}

\begin{tabular}{|l|l|}
\hline Control & TA \\
\hline
\end{tabular}

Figure 6: Mean values $\pm S E$ of liver thiobarbituric acid-reactive substances (TBARS; $n$ mole/gm tissue), reduced glutathione (GSH; $\mu$ mole/gm tissue), superoxide dismutase (SOD; U/gm tissue), glutathione peroxidase (GPx; U/gm tissue), and glutathione S-transferase (GST;

$\mu$ mole/hr/gm tissue), catalase (CAT; U/gm tissue)
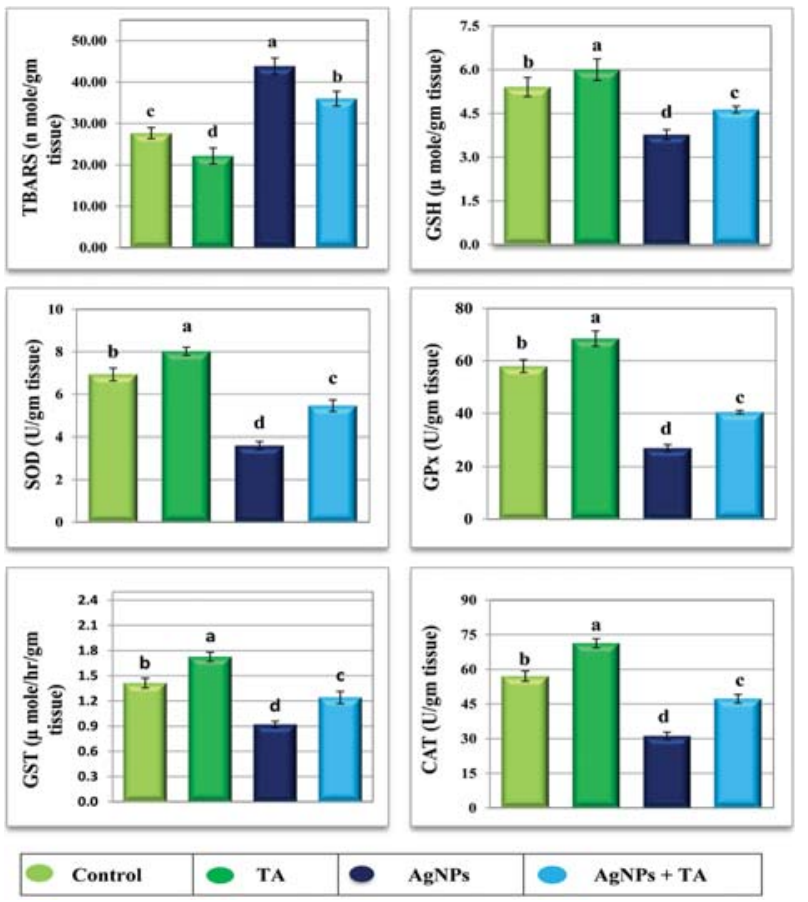

Figure 7: Mean values $\pm S E$ of kidney thiobarbituric acid-reactive substances (TBARS; $n$ mole/gm tissue), reduced glutathione (GSH; $\mu$ mole/gm tissue), superoxide dismutase (SOD; U/gm tissue), glutathione peroxidase (GPx; U/gm tissue), glutathione S-transferase (GST; $\mu$ mole/hr/gm tissue), catalase (CAT; U/gm tissue)
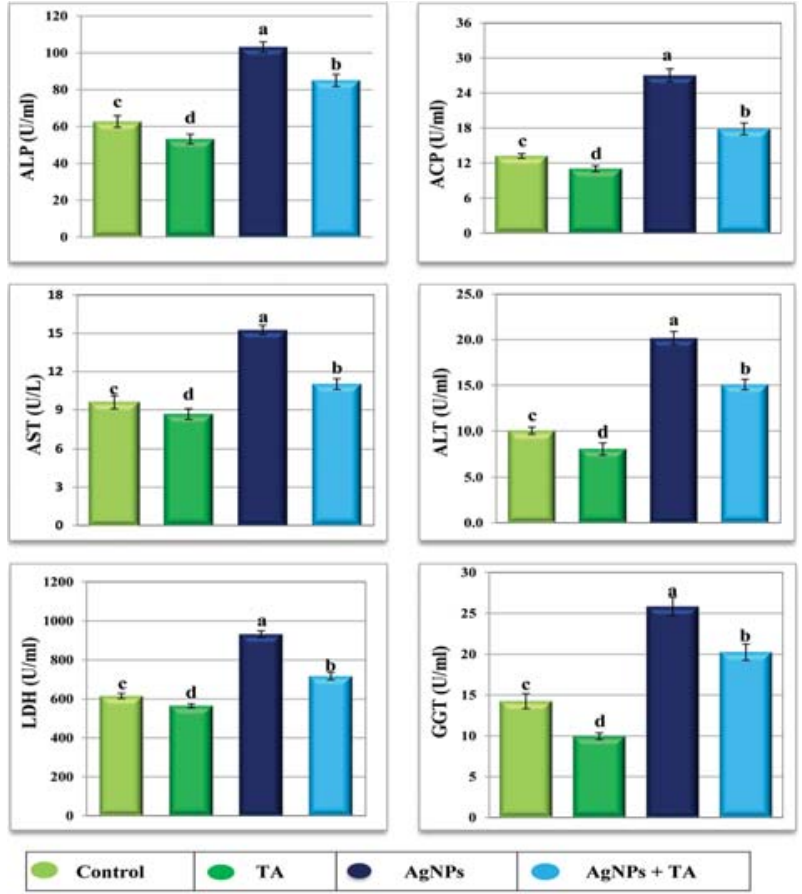

Figure 8: Mean values $\pm S E$ of plasma alkaline phosphatase (ALP; U/ml), acid phosphatase (ACP; U/ml), aspartate transaminase (AST; U/L), alanine transaminase (ALT; U/ml), plasma lactate dehydrogenase ( $L D H$; $U / \mathrm{ml})$, gamaglutamyle transaminase (GGT; U/ml) of male rats treated with tannic acid, silver nanoparticle and their combination
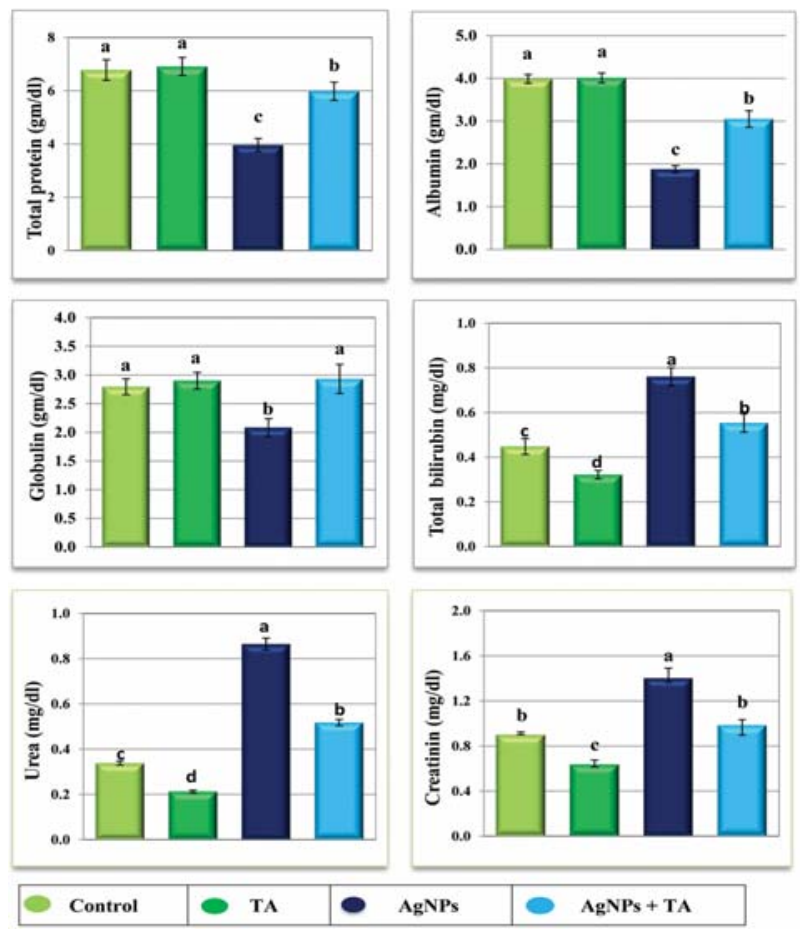

Figure 9: Mean values $\pm S E$ of plasma total protein $(\mathrm{gm} / \mathrm{dl})$, albumin $(\mathrm{gm} / \mathrm{dl})$, globulin $(\mathrm{gm} / \mathrm{dl})$, Total bilirubin $(\mathrm{mg} / \mathrm{dl})$, urea $(\mathrm{mg} / \mathrm{dl})$ and creatinine $(\mathrm{mg} / \mathrm{dl})$ of male rats treated with tannic acid, silver nanoparticles and their combination 
and their combination for 77 days. Results showed that treatment with AgNPs significantly $(\mathrm{P}<0.05)$ increaseed plasma ALP, ACP, LDH and GGT activities compared to control group. On the other hand, treatment with tannic acid alone caused significant $(\mathrm{P}<0.05)$ decrease in the activities of these enzymes compared to control group. The combination group showed significant decrease in the activities of studied enzymes compared to AgNPs treated grup.
The mean values of plasma total protein, albumin, globulin, total bilirubin, urea and creatinine after 77 days experimental period was shown in Table 4 and Figure 9. Treatment with AgNPs alone resulted in a significant $(\mathrm{P}<0.05)$ decrease in total protein, albumin and globulin, and a significant $(\mathrm{P}<0.05)$ increase in plasma total bilirubin, urea, and creatinine compared to control group. While, treatment with tannic acid alone showed non-significant increase in plasma levels of to-

Table 3. Plasma enzyme activities of male rats treated with tannic acid, silver nanoparticles (AgNPs) and their combination

\begin{tabular}{|l|c|c|c|c|}
\hline \multirow{2}{*}{\multicolumn{1}{|c|}{ Parameter }} & \multicolumn{4}{|c|}{ Experimental groups } \\
\cline { 2 - 5 } & Control & Tannic acid & AgNPs & AgNPs + Tannic acid \\
\hline ALP (U/L) & $62.80 \pm 3.16^{\mathrm{c}}$ & $53.23 \pm 2.64^{\mathrm{d}}$ & $103.18 \pm 2.78^{\mathrm{a}}$ & $85.08 \pm 3.29^{\mathrm{b}}$ \\
\hline ACP (U/L) & $13.23 \pm 0.41^{\mathrm{c}}$ & $11.05 \pm 0.53^{\mathrm{d}}$ & $27.03 \pm 1.13^{\mathrm{a}}$ & $17.85 \pm 1.02^{\mathrm{b}}$ \\
\hline AST(U/L) & $9.58 \pm 0.50^{\mathrm{c}}$ & $8.67 \pm 0.41^{\mathrm{d}}$ & $15.28 \pm 0.37^{\mathrm{a}}$ & $11.03 \pm 0.43^{\mathrm{b}}$ \\
\hline ALT(U/L) & $10.04 \pm 0.42^{\mathrm{c}}$ & $8.11 \pm 0.76^{\mathrm{d}}$ & $20.18 \pm 0.83^{\mathrm{a}}$ & $15.08 \pm 0.67^{\mathrm{b}}$ \\
\hline LDH (U/L) & $615.0 \pm 5.78^{\mathrm{c}}$ & $564.3 \pm 8.85^{\mathrm{d}}$ & $931.7 \pm 16.94^{\mathrm{a}}$ & $715.8 \pm 8.33^{\mathrm{b}}$ \\
\hline GGT (U/L) & $14.25 \pm 0.91^{\mathrm{c}}$ & $9.94 \pm 0.41^{\mathrm{d}}$ & $25.85 \pm 1.13^{\mathrm{a}}$ & $20.25 \pm 1.00^{\mathrm{b}}$ \\
\hline
\end{tabular}

* Mean values within a column not sharing a common superscript letter ( $\mathrm{a}, \mathrm{b}, \mathrm{c}$ ) were significantly different, $\mathrm{p}<0.05$.

*ALP $=$ Alkaline phosphatase, $\mathrm{ACP}=$ Acid phosphatase, $\mathrm{AST}=$ Aspartate transaminase, $\mathrm{ALT}=$ Alanine transaminase, $\mathrm{LDH}=\mathrm{Lac}-$ tate dehydrogenase, GGT = Gamaglutamyle transaminase.

Table 4. Plasma total protein, albumin, globulin, total bilirubin, urea and creatinine of male rats treated with Tannic acid, silver nanoparticles (AgNPs) and their combination

\begin{tabular}{|l|c|c|c|c|}
\hline \multirow{2}{*}{\multicolumn{1}{c|}{ Parameter }} & \multicolumn{4}{|c|}{ Experimental groups } \\
\cline { 2 - 5 } & Control & Tannic acid & AgNPs & AgNPs + Tannic acid \\
\hline Total protein (g/dl) & $6.78 \pm 0.38^{\mathrm{a}}$ & $6.91 \pm 0.34^{\mathrm{a}}$ & $3.96 \pm 0.25^{\mathrm{c}}$ & $5.98 \pm 0.34^{\mathrm{b}}$ \\
\hline Albumin (g/dl) & $3.99 \pm 0.10^{\mathrm{a}}$ & $4.01 \pm 0.12^{\mathrm{a}}$ & $1.88 \pm 0.08^{\mathrm{c}}$ & $3.05 \pm 0.19^{\mathrm{b}}$ \\
\hline Globulin (g/dl) & $2.79 \pm 0.14^{\mathrm{a}}$ & $2.80 \pm 0.14^{\mathrm{a}}$ & $2.08 \pm 0.16^{\mathrm{b}}$ & $2.93 \pm 0.26^{\mathrm{a}}$ \\
\hline Total bilirubin (mg/dl) & $0.45 \pm 0.04^{\mathrm{c}}$ & $0.32 \pm 0.02^{\mathrm{d}}$ & $0.76 \pm 0.04^{\mathrm{a}}$ & $0.55 \pm 0.04^{\mathrm{b}}$ \\
\hline Urea (mg/dl) & $0.34 \pm 0.1^{\mathrm{c}}$ & $0.21 \pm 0.01^{\mathrm{d}}$ & $0.87 \pm 0.03^{\mathrm{a}}$ & $0.52 \pm 0.02^{\mathrm{b}}$ \\
\hline Creatinine (mg/dl) & $0.90 \pm 0.03^{\mathrm{b}}$ & $0.64 \pm 0.04^{\mathrm{c}}$ & $1.40 \pm 0.10^{\mathrm{a}}$ & $0.98 \pm 0.06^{\mathrm{b}}$ \\
\hline
\end{tabular}

* Mean values within a column not sharing a common superscript letter (a, b, c) were significantly different, $\mathrm{p}<0.05$.

Table 5. Hematological parameters of male rats treated with Tannic acid, silver nanoparticles (AgNPs) and their combination

\begin{tabular}{|l|c|c|c|c|}
\hline \multirow{2}{*}{\multicolumn{1}{|c|}{ Parameter }} & \multicolumn{4}{|c|}{ Experimental groups } \\
\cline { 2 - 5 } & Control & Tannic acid & AgNPs & AgNPs + Tannic acid \\
\hline RBC $\left(10^{6} / \mathrm{ml}\right)$ & $6.27 \pm 0.52^{\mathrm{b}}$ & $7.07 \pm 0.43^{\mathrm{a}}$ & $4.19 \pm 0.10^{\mathrm{d}}$ & $5.31 \pm 0.22^{\mathrm{c}}$ \\
\hline $\mathrm{HGB}(\mathrm{g} / \mathrm{dl})$ & $21.48 \pm 1.23^{\mathrm{b}}$ & $23.91 \pm 1.17^{\mathrm{a}}$ & $16.53 \pm 0.91^{\mathrm{d}}$ & $18.64 \pm 0.53^{\mathrm{c}}$ \\
\hline $\mathrm{HCT}(\%)$ & $32.58 \pm 1.25^{\mathrm{b}}$ & $36.73 \pm 1.60^{\mathrm{a}}$ & $24.60 \pm 1.85^{\mathrm{d}}$ & $27.90 \pm 1.45^{\mathrm{c}}$ \\
\hline $\mathrm{MCV}(\mathrm{fl})$ & $55.50 \pm 3.13^{\mathrm{b}}$ & $62.67 \pm 1.76^{\mathrm{a}}$ & $41.33 \pm 1.33^{\mathrm{d}}$ & $49.83 \pm 1.45^{\mathrm{c}}$ \\
\hline $\mathrm{MCH}(\mathrm{pg})$ & $35.15 \pm 2.21^{\mathrm{b}}$ & $39.75 \pm 1.72^{\mathrm{a}}$ & $25.90 \pm 1.50^{\mathrm{d}}$ & $30.67 \pm 1.61^{\mathrm{c}}$ \\
\hline $\mathrm{MCHC}(\mathrm{pg})$ & $71.42 \pm 2.09^{\mathrm{b}}$ & $80.17 \pm 2.44^{\mathrm{a}}$ & $55.73 \pm 1.91^{\mathrm{d}}$ & $61.25 \pm 2.23^{\mathrm{c}}$ \\
\hline PLT $\left(10^{3} / \mathrm{ml}\right)$ & $183.67 \pm 5.4^{\mathrm{b}}$ & $207.3 \pm 9.35^{\mathrm{a}}$ & $66.17 \pm 4.13^{\mathrm{d}}$ & $112.17 \pm 3.26^{\mathrm{c}}$ \\
\hline $\mathrm{WBC}\left(10^{3} / \mathrm{ml}\right)$ & $11.4 \pm 0.52^{\mathrm{cd}}$ & $12.7 \pm 0.43^{\mathrm{c}}$ & $17.0 \pm 0.10^{\mathrm{a}}$ & $14.4 \pm 0.22^{\mathrm{b}}$ \\
\hline
\end{tabular}

* Mean values within a column not sharing a common superscript letter ( $\mathrm{a}, \mathrm{b}, \mathrm{c}$ ) were significantly different, $\mathrm{p}<0.05$.

$* \mathrm{RBC}=$ red blood cells, $\mathrm{HGB}=$ hemoglobin, $\mathrm{HCT}=$ hematocrit value, $\mathrm{MCV}=$ mean corpuscular volume, $\mathrm{MCH}=$ mean corpuscular hemoglobin, $\mathrm{MCHC}=$ mean corpuscular hemoglobin concentration, $\mathrm{PLT}=$ platelets $\left(10^{3} / \mathrm{ml}\right)$ and $\mathrm{WBC}=$ white $\operatorname{blood}$ cells $\left(10^{3} / \mathrm{ml}\right)$. 
tal protein, albumin and globulin, and non-significant $(\mathrm{P}<0.05)$ decrease in plasma total bilirubin, urea and creatinine compared to the control group. On the other hand, the presence of tannic acid with AgNPs in the combination group increased the concentration of plasma total protein, albumin and globulin, and decreased plasma total bilirubin, urea and creatinine. But these values did not reach the values of control group.

\section{Hematological parameters}

Table 5 and Figure 10 represented the mean values of the hematological parameters (white blood cells; WBCs, red blood cells; RBC, hemoglobin; HGB, hematocrit value; $\mathrm{HCT}$, mean corpuscular volume; $\mathrm{MCV}$, mean corpuscular hemoglobin; $\mathrm{MCH}$, mean corpuscular hemoglobin concentration; MCHC, platelets; PLT) of male rats treated with tannic acid, silver nanoparticles, and their combination for 77 days. Results showed that treatment with AgNPs caused significant $(\mathrm{P}<0.05)$ increase in WBCs, while caused significant $(\mathrm{P}<0.05)$ decrease in RBC, HGB, HCT, MCV, MCH, MCHC and PLT compared to control group. On the other hand, treatment with tannic acid alone caused significant $(\mathrm{P}<$ $0.05)$ decrease in WBCs and caused significant $(\mathrm{P}<$ 0.05 ) increase in $\mathrm{RBC}, \mathrm{HGB}, \mathrm{HCT}, \mathrm{MCV}, \mathrm{MCH}$, $\mathrm{MCHC}$ and PLT compared to control. Results showed that the presence of tannic acid along with AgNPs in
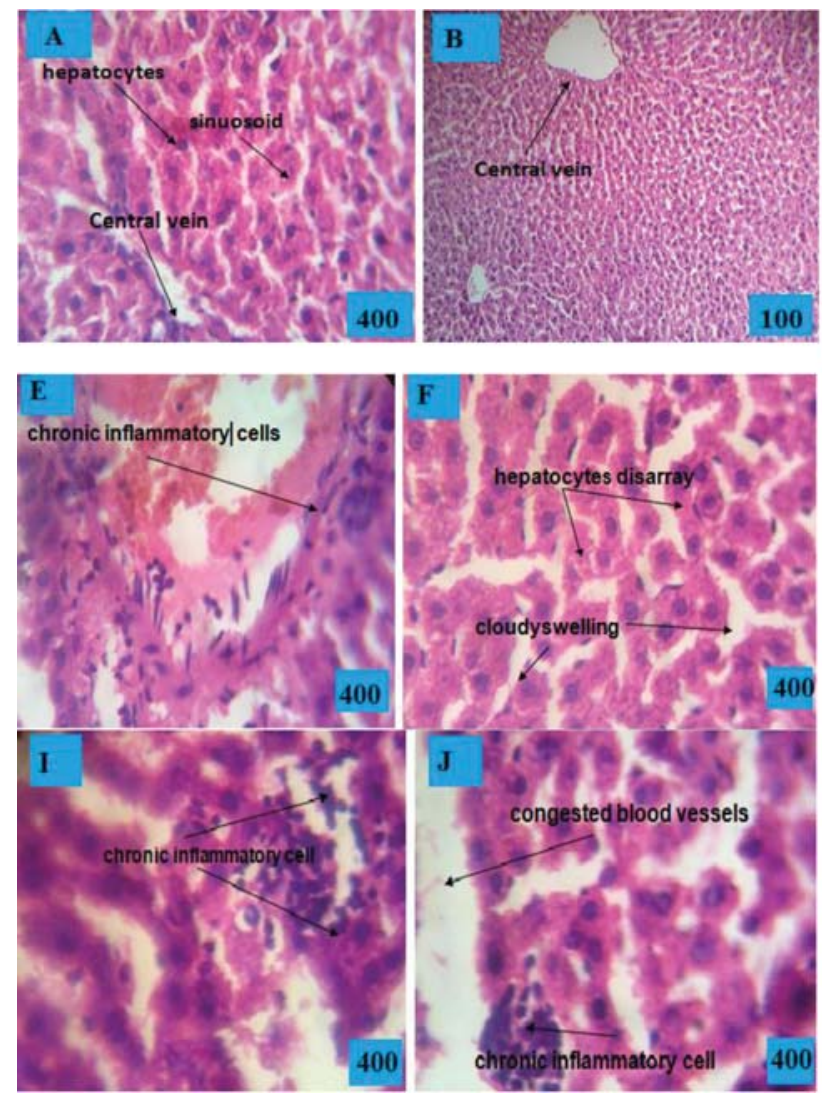
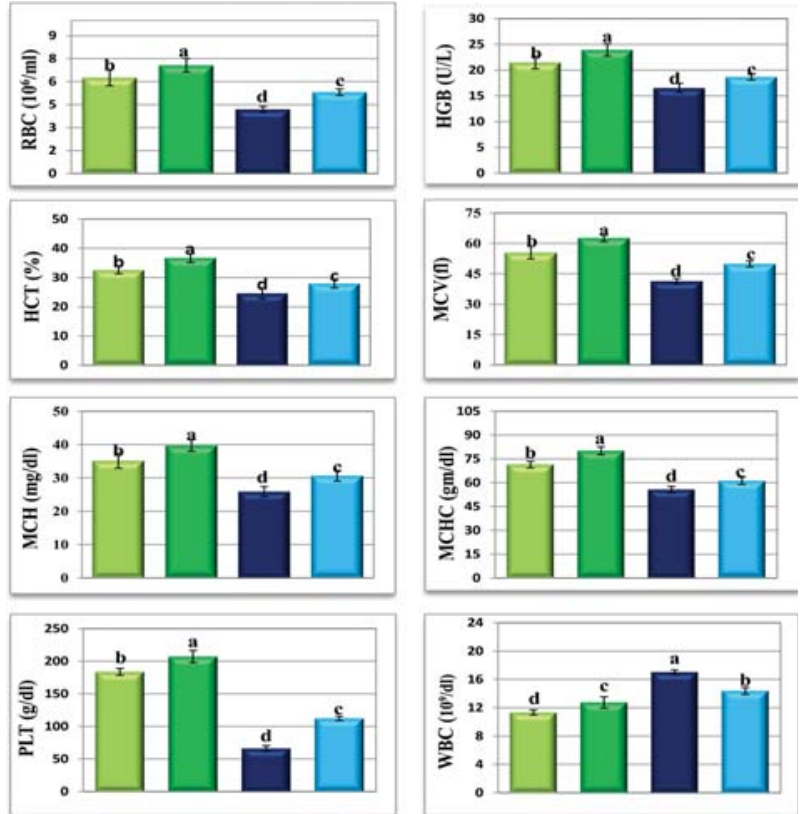

\begin{tabular}{|l|l|l|l|}
\hline Control & TA & - AgNPs & AgNPs + TA \\
\hline
\end{tabular}

Figure 10: Mean value $\pm S E$ of red blood cells (RBC; $10^{6} / \mathrm{ml}$ ), hemoglobin (HGB; U/L) and hematocrit (HCT; \%), mean corpuscular volume (MCV; fl), mean corpuscular hemoglobin (MCH; mg/dl), mean corpuscular hemoglobin concentration (MCHC; gm/dl), platelets (PLT; g/dl) and white blood cells (WBC; $\left.10^{9} / \mathrm{dl}\right)$ of male rats treated with tannic acid, silver nanoparticles and their combination
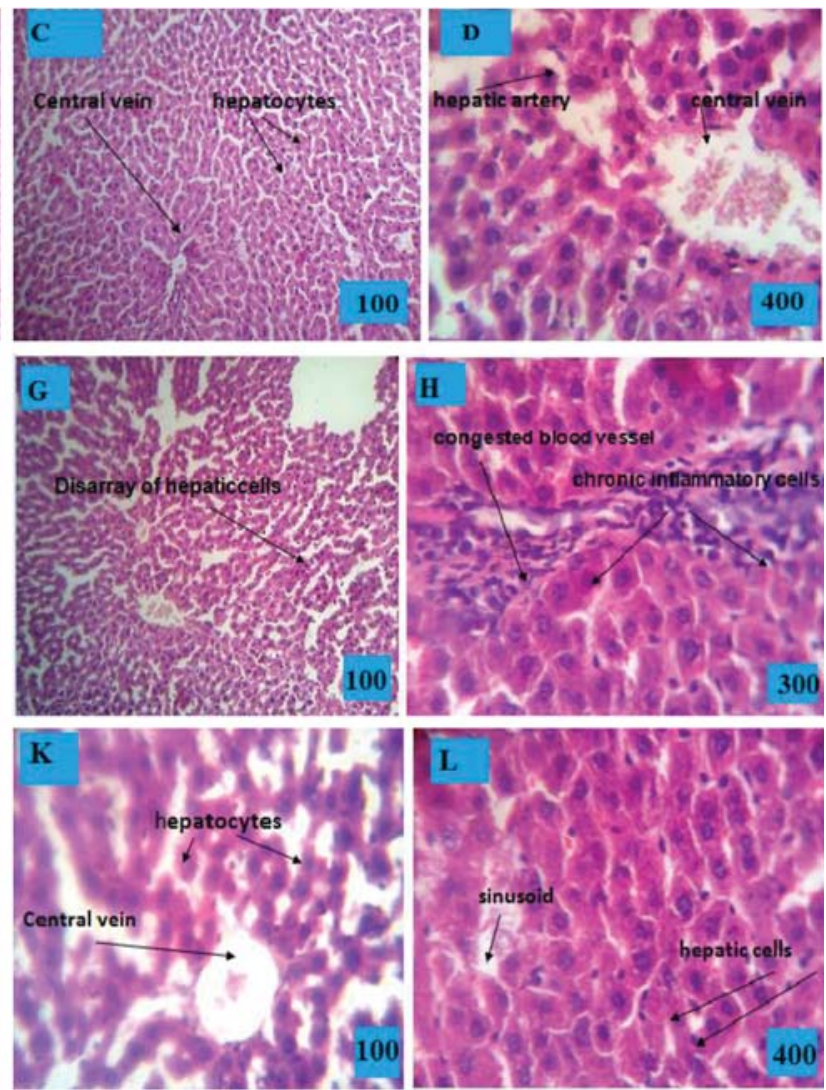

Figure 11: Photomicrographs of rat liver sections of different experimental groups stained by $H \& E$ 
the combination group caused minimization of the toxicity of AgNPs compared to AgNPs treated group.

\section{Histopathological parameters of liver and kidney}

Photomicrograph of the liver of control rats (Figure $11(\mathrm{~A}$ and $\mathrm{B})$ ) showed normal structure hepatocytes having normal eosinophilic cytoplasm, round nuclei, central vein, portal tracts and blood sinusoids. Photomicrograph of liver of rats treated with tannic acid (Figure 11C) showed also normal structure of hepatocytes having normal eosinophilic cytoplasm, round nuclei central vein, portal tracts and blood sinusoids, while (Figure 11D) showed hepatic lobule, hepatocytes surrounding central vein and normal hepatic artery. Photomicrograph of rats' sliver treated with silver nanoparticles Figure 11(E-J) showed hepatocytes revealed hydropic change, sinusoidal dilatation, Kupffer cell hyperplasia, moderate portal inflammation and piecemeal. Lobular infiltrate by chronic inflammatory cells congested hepatic sinusoids containing red blood cells, with hepatocytes disarray and cloudy swelling is liver hepatocytes (sinusoid). Photomicrograph of liver of
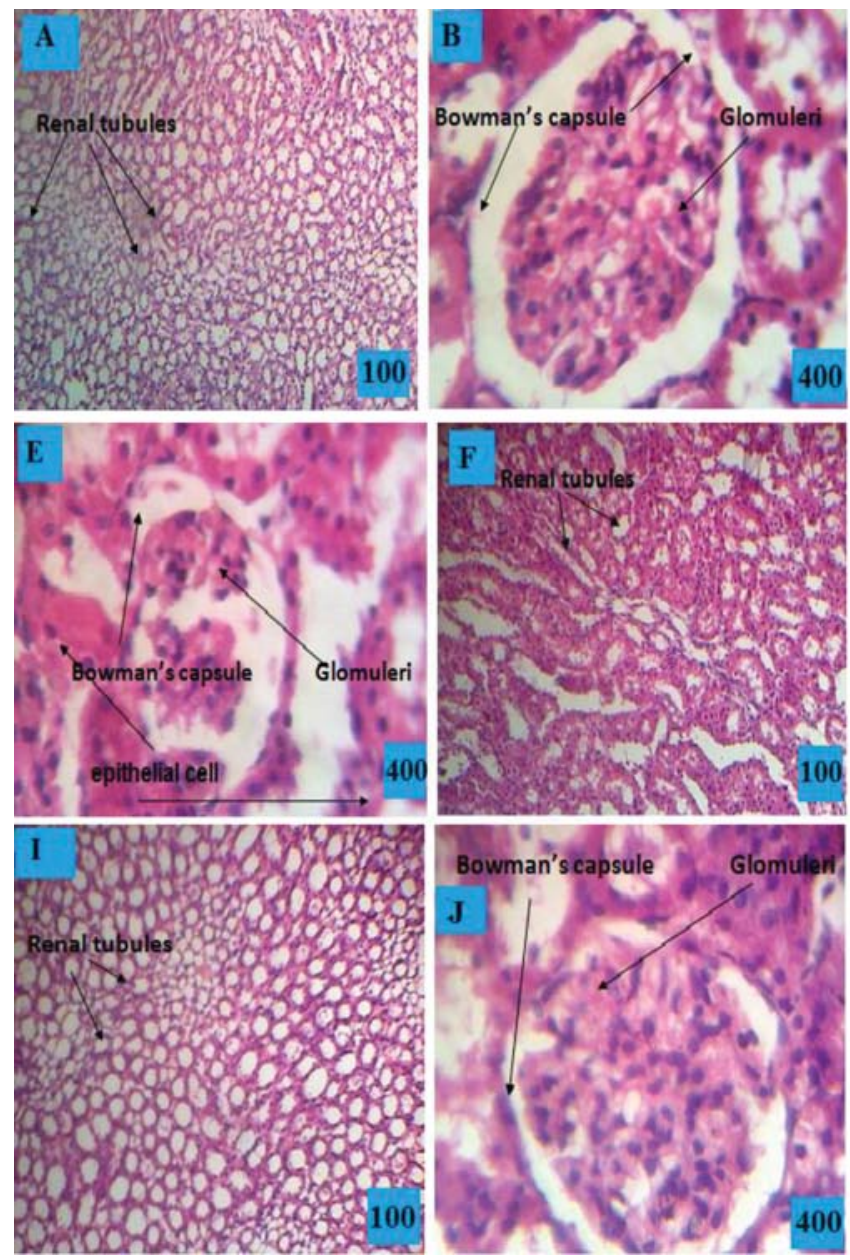

rats treated with AgNPs and tannic acid (Figure 11(K and L)) showed improvement of the portal area and a decrease of the inflammation and infiltration of the portal area and hepatocytes.

Photomicrograph of kidney of control rats (Figure 12 (A and B)) showed normal glomeruli and tubules. Also, photomicrograph of rats treated with tannic acid (Figure 12 (C and D)) showed normal glomeruli and tubules in kidney. The tubules are lined by low cuboidal epithelium with eosinophilic cytoplasm. The glomeruli have normal epithelial, endothelial and mesangial cells. Photomicrograph of rats treated with silver nanoparticles showed slightly degeneration and epithelial cell necrosis, in the epithelial lining some of the tubules and mononuclear cell infiltration in the interstitium (Figure 12 (E and F)). Also, treatment with silver nanoparticles showed increase degeneration and renal tubules necrosis in the epithelial lining, some of the tubules and mononuclear cell infiltration in the interstitium, eosinophilic secretion in the tubules lumen and vascularity of glomerular in the Bowman's capsule (Figure $12(\mathrm{G}$ and $\mathrm{H})$ ). While Photomicrograph of rats treated with silver nanoparticles and tannic acid showed improvement of the degeneration and epithelial
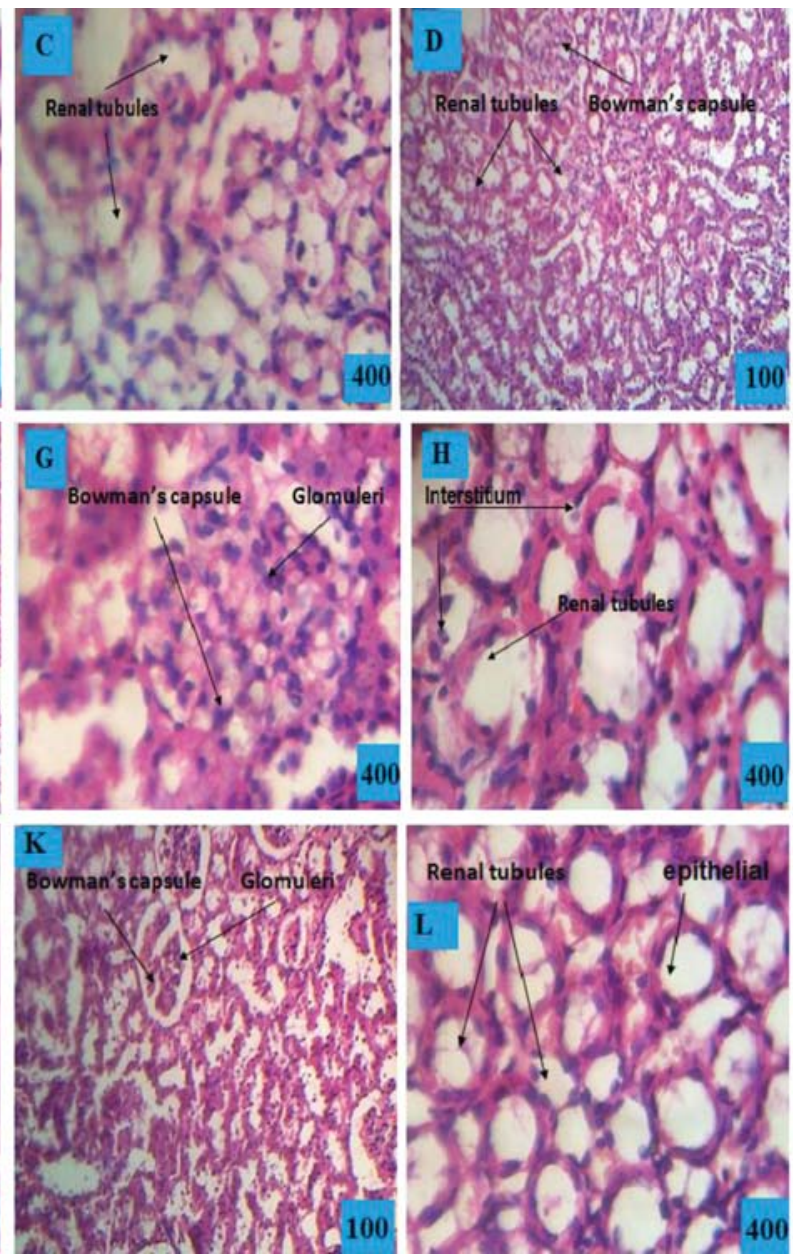

Figure 12: Photomicrographs of rat kidney sections of different experimental groups stained by $H \& E$ 
cell necrosis, in the epithelial lining: some of the tubules and mononuclear cell infiltration in the interstitium and decrease of eosinophilic secretion in the tubules lumen (Figure 12(I-L)).

\section{DISCUSSION}

Silver nanoparticles are one of the most commercialized nanoparticles worldwide and its toxicology became an important area of research. As a result of their extremely small size, AgNPs has shown unique chemical and physical characteristics with certain biological effects, which with its role make them attractive in several consumer products. However, these properties also highlight the potential toxicity of AgNPs [34]. Kovvuru et al. (35) and Sarhan \& Hussein (36) have investigated the in vivo and in vitro toxicological effects of AgNPs, showing that with different routes of exposure, certain size and doses, AgNPs could lead to harmful effects in living organisms. Due to AgNPs relative safety as compared to other nanomaterials, short-term studies at low doses have not shown any significant adverse effects of AgNPs. However, there are limited numbers of long-term animal studies, especially on the renal and hepatic system. These studies are required because the release of silver ions by surface oxidation and the nano-crystalline solubility of silver are much higher than metallic silver (37). Silver ions also have strong relationship to sulfhydryl groups of amino acids and proteins causing their precipitation and modifications (38).

Induction of oxidative stress is the major mechanism of toxicity of surrounding nanoparticles (39). By disturbing the balance between antioxidant and oxidant processes, nanoparticles enter the cell and induce intracellular oxidative stress. Extravagant oxidative stress may also modify proteins, lipids and nucleic acids, which stimulates the defense system of antioxidant or even leads to cell apoptosis (40). He et al. (41) demonstrated that with elevated concentrations of AgNPs, epithelial cells morphology can change to become more fusiform and less polyhedral, rounded and shrunken, because AgNPs elevate the levels of oxidative stress by decreasing the levels of GSH and SOD, and increasing lipid peroxidation, which finally leads to apoptosis by increasing DNA fragmentation and caspase-3 activity. Upon AgNPs interaction with proteins membrane, AgNPs and $\mathrm{Ag}^{+}$may trigger lipid peroxidation and increase cell membrane permeation. Cell membrane damage leads to cytoplasmic contents leakage, such as $\mathrm{LDH}$, and eventually ends up with cell necrosis, while rupture of lysosomal membranes releases cathepsins into the cytoplasm, activating lysosome-mediated apoptosis (40). Furthermore, mitochondrial damage impairs electron transfer, inhibits adenosine triphosphate (ATP) synthesis, triggers oxidative stress, and activates mitochondrion-dependent apoptosis $(40,42)$. In a previous study, AgNPs has been administered intraperitoneally to mice at very high doses $(100,500,1000$ $\mathrm{mg} / \mathrm{kg} \mathrm{BW}$ ) leading to multiple genes alterations in brain's mouse, including genes associated with oxidative stress and inflammation (43). Existing toxicokinetic data indicates that liver, which is the principal detoxifying organ maintaining metabolic homeostasis, accumulates high concentrations of AgNPs (44). For metabolizing various toxic compounds, liver possesses one of the active antioxidant defense system in order to preserve antioxidative/oxidative balance (45). Hence, the present study was designed to indicate AgNPs influence on oxidative stress generation and the activity of enzymatic antioxidant systems in liver and kidney tissues of intraperitoneally treated rats for 77 consecutive days.

Under physiological conditions, the efficient action of enzymatic and non-enzymatic antioxidant defense systems has prevented the damage caused by ROS. SOD, CAT and GPx are the enzymes providing the first line defense against hydrogen and superoxide peroxide. Our results indicated that antioxidant enzymes inhibition in liver and kidney of rats exposed to AgNPs is good evident. We observed that exposure of rats to AgNPs caused statistically significant decrease in GST, GPx, SOD and CAT activities, and GSH levels in liver and kidney. Results of Skalska et al. (46) revealed that GSH/GSSG ratio decreased in brain after exposure to both forms of silver ( $\left.\mathrm{AgNPs} / \mathrm{Ag}^{+}\right)$, although no change in the level of total glutathione (tGSH) was observed. This reflects increased rates of GSH oxidation to glutathione disulfide (GSSG) as an effect of increased S-thiolation of critical protein thiols and/or direct ROS scavenging.

Liver has been reported as one of the target organs and a predominant site of accumulation of nanoparticles (47). A previous study has demonstrated that AgNPs administration to rats caused significant alterations to the ALP levels (48). Also, Garcia et al. (34) found signiWcant increase of AgNPs levels in liver and signiWcant alterations in enzymatic liver markers. Alanine aminotransferase (ALT) and aspartate aminotransferase (AST) are a cytoplasmic in location and only largely released into circulation after hepatocyte structural integrity damage; thus, their activities are most commonly used as reliable markers for clinical monitoring of liver function or liver injury (49). Here, the activities of alkaline phosphatase (ALP), acid phosphatase (ACP), aspartate transaminase (AST), alanine transaminase (ALT), lactate dehydrogenase (LDH), gamaglutamyle transaminase (GGT) increase 
in plasma signing a hepatic harmful effect in rats treated with silver nanoparticles. Also, Ebabe Elle et al. (9) found same results in rats exposed to $500 \mathrm{mg} / \mathrm{d} / \mathrm{kg} \mathrm{BW}$ AgNPs for 81 days. The potential of AgNPs to modulate enzyme activity was attributable to their affinity for thiol groups. It is probable that thiol groups in the enzymes made them attractive to AgNPs leading to formation of complexes and consequent modulation of enzyme activity (50).

The decrease in total protein might be due to decreased synthesis, increased loss, increased catabolism, malabsorption or liver disease consequent upon the administration of nanoparticles $(51,52)$. Braydich-Stolle et al. (53) suggested that plasma albumin concentration may be directly altered, as a result of the loss of albumin through damaged glomeruli in case of renal failure. Consequently, in the present study, the significant decrease in albumin may be evidence on AgNPs-induced nephrotoxicity. Silver nanoparticles increase membrane leakage in mammalian germ line stem cells and increase ROS generation, deplete antioxidant reduced glutathione (GSH) content, and reduce mitochondrial function in rat liver cells. Albendea et al. (54) reported that the depletion in the levels of total protein lead to inhibition of antioxidant enzymes. Proteins are necessary for enzyme synthesis, and any factor blocking the process of protein synthesis will in turn reduce the synthesis of enzymes, including antioxidant enzymes, and consequently lead to the inhibition of these enzymes and this is conformed with the obtained results of liver enzymes. Urea and creatinine are waste products of protein metabolism that need to be excreted by the kidney and increase of these factors is an indication of functional damage to the kidney (55). The level of blood creatinine is proportional to the glomerular filtration rate. Moreover, urea plays an important role in the metabolism of compounds containing protein in animal body (56). Adeyemi and Sulaiman (57) demonstrated that increased red blood cell hemolysis could cause elevated bilirubin beyond the hepatic function capacity. A rise in the level of serum urea may imply impaired renal excretion (58).

Naghsh et al. (59) demonstrated that rats treated with silver nanoparticles, exhibit elevated number of WBC. They justified this phenomenon with the immune response of rats to an external factor causing an increase of the number of white blood cells for phagocytosis of silver nanoparticles. With attention to decrease number of $\mathrm{RBC}$, the falling of $\mathrm{RBC}$ can be related to suppressive effect of AgNPs on pluripotent stem cells, producing blood cells, in bone marrow. Lovrić et al. (60) reported that after AgNPs absorption into the GIT, it was capable to enter the blood circulation system, therefore these particles can potentially interact with different metabolites such as: plasma proteins, coagulation factors, platelets, red and white blood cells. For this reason, AgNPs perhaps induce oxidative stress and affect the structure and physiology of the cells adversely, oxidative metabolism, fat membrane structure and function that can destroy red and white blood cells and susceptibly pass reticuloendothelial system of spleen and liver (23). However, no significant effects in hematological parameters were found after 90 days of treatment with different doses of $\operatorname{AgNPs}(34,61)$.

Histopathological changes in liver and kidney of rats treated with AgNPs, which noted in the present study agrees with the obtained data that showed changes in the levels of biochemical parameters in liver and kidney. Arora et al. (62) has found that internalized AgNPs can disrupt the cell membrane integrity, cause lysosomal swelling, and even rupture lysosomal membranes. Tiwari et al. (63) reported that some histopathological changes were observed in kidney of animals treated with AgNPs. Hematoxylin and eosin (H\&E) and periodic acid-Schiff (PAS) staining of kidney sections showed damage to basement membrane and brush borders of proximal tubules along with overall decrease in urinary space. TEM analysis indicated significant submicroscopic damage in kidney. Large number of mitochondria were swollen or completely ruptured with total loss of their content. There was pronounced swelling of podocytes with fusion of their foot processes that may affect the glomerular filtration. Such type of submicroscopic changes has been also previously reported in intravenous and subcutaneous treatments $(64,65)$. These symptoms resemble those observed in 'Minimal change disease' of the kidney, where there are few light microscopic indicators but major changes at the ultramicroscopic level. As reported earlier, this could later lead to development of nephritic syndrome (66) and other chronic diseases of the kidney. TEM analysis also confirmed localization of AgNPs in particle form in the kidney. Also, Tiwari et al. (63) found that kidney sections examination by TEM showed necrotic cellular damage in proximal convoluted tubule (PCT) and distal convoluted tubule (DCT) of animals treated with AgNPs. There was dilation of cellular organelle (mitochondria, endoplasmic reticulum, and Golgi apparatus), damage to plasma membrane, swelling of cells and moderate chromatin condensation which are characteristics of necrotic cell death (67). Tiwari et al. (63) observed significant ROS induced DNA damage in AgNPs treated animals by oxo-8G staining of kidney sections. This was also associated with high levels of ROS and lower GSH/GSSG. Toxic endpoints seen in our study may be cumulative effect of both AgNPsand released ions have been reported previously $(63,68)$. 
Tannic acid is an antioxidant compound, which comprises polyphenolic compound that have been utilized to mitigate various conditions of oxidative stress. Its antioxidant action is believed to originate from its ability to stimulate glutathione (GSH) synthesis, therefore, maintaining intracellular GSH levels (69). Several authors have demonstrated that tannic acid and other polyphenols have antimutagenic and anticarcinogenic activities. Moreover, the consumption of polyphenol-rich fruits, vegetables, and beverages, such as red wine and tea, has been linked with preventive and inhibitory effects in various human cancers and cardiovascular diseases, which may be related at least in part with the antioxidant activity of polyphenols (70). Also, the present data showed that tannic acid decreased the levels of free radicals and increased the activities of antioxidant enzyme therefore minimized the toxic effects of silver nanoparticles. Therefore, the present results showed that tannic acid co-treatment with AgNPs reduced its hepato-renal damage via increasing the activities of antioxidant enzymes in liver and kidney.

\section{CONCLUSION}

Finally, we reported that in vivo and intraperitoneally treatment with silver nanoparticles induced deleterious effects on liver and kidney and led to oxidative stress, biochemical and histological changes, and hematotoxicity. Also, our results showed that using tannic acid as antioxidant was capable to alleviate harmful effects of silver nanoparticles on liver and kidney functions to protect healthy tissues and to reduce AgNPs toxicity. Finally, we suggest using tannic acid as a preventive agent along with silver nanoparticles to minimize its hepato-nephrotoxicity.
Abbreviations
GPx - Glutathione peroxidase
GST - Glutathione S-transferase
I.p. - Intraperitoneally
NO - Nitric oxide
ROS - Reactive oxygen species
GSH - Reduced glutathione
SOD - Superoxide dismutase
TBARS - Thiobarbituric acid reactive substances
TAC - Total antioxidant capacity
TAG - Triacylglycerol
AgNPs - Silver Nanoparticles tathione

GSH/GSSG - Ratio of reduced-to-oxidized glu-
BBB - Blood Brain Barrier
ATP - Adenosine Triphosphate
RNS - Reactive Nitrogen Species
IR - Insulin Receptor
ATPase - Adenosine-triphosphatase
TA - Tannic acid
CAT - Catalase
RBCs - Red Blood Cells
HGB - Hemoglobin
HCT - Hematocrit
MCV - Mean Corpuscular Volume
MCH - Mean Corpuscular Hemoglobin
MCHC - Mean Corpuscular Hemoglobin concentration
WBCs - White Blood Cells
PLT - Platelets
AST - Aspartate Transaminase
ALT - Alanine Transaminase
ALP - Alkaline Phosphatase
ACP - Acid Phosphatase
LDH - Lactate Dehydrogenase
GGT - Gamma glutamyte transaminase
TEM - Transmission Electron Microscope
SEM - Scanning Electron Microscopy
XRD - X-ray Diffractometer
FCC - Face-centered Cubic
FT-IR - Fourier Transform Infrared
LPO - Lipid peroxidation
GR - Glutathione Reductase
GPT - Glutamic pyruvic transaminase
GOT - Glutamic oxaloacetic transaminase
GIT - Gastrointestinal tract

\section{Acknowledgement and Funding}

Firstly, I thank Allah the most gracious. This journey would not have been possible without the support of my family, professors and mentors. To my family, thank you for encouraging me in all my pursuits and inspiring me to follow my dreams. I am grateful to my parents, who supported me emotionally and financially. I always knew that they believed in me and wanted the best for me. I heribly acknowledge that this paper has received No funding.

Conflict of Interests: The authors declare that there are no conflicts of interest related to this article.

\section{Licensing}

This work is licensed under a Creative Commons Attribution 4.0 International (CC BY 4.0) License. 


\title{
Sažetak
}

\section{PROTEKTIVNA ULOGA TANINSKE KISELINE U KORELACIJI SA MOGUĆOM HEPATO-NEFROTOKSIČNOŠĆU INDUKOVANOJ NANOČESTICAMA SREBRA KOD MUŽJAKA PACOVA}

\author{
Mosa F Israa, ${ }^{1 *}$ Youssef Mokhtar, ${ }^{2}$ Shalaby Thanaa, ${ }^{3}$ Mosa F Osama ${ }^{4}$ \\ ${ }^{1 *}$ Department of Environmental Studies, Institute of Graduate Studies and Research, Alexandria University, Alexandria, Egypt \\ ${ }^{2}$ Department of Environmental Studies, Institute of Graduate Studies and Research, Alexandria University, Alexandria, Egypt \\ ${ }^{3}$ Department of Biophysics, Medical Research Institute, Alexandria University Alexandria, Egypt \\ ${ }^{4}$ Department of Public Health, Health Sciences College at Leith, Umm Al Qura University, Al-Leith, Makkah, Saudi Arabia
}

Nanočestice srebra (AgNPs) se ekstenzivno koriste u biomedicinske svrhe, zbog njihove široke antimikrobne aktivnosti. Međutim njihova toksičnost je opisivana u par studija do sada. Cilj ove studije bio je da se pripreme AgNPs, da se ispitaju neželjeni efekti ovih čestica na hepatične i na bubrežne funkcije, kao i da se bliže objasne hepato-nefrotoksične aktivnosti taninske kiseline kod pacova mužjaka. Dobijeni rezultati su pokazali da AgNPs izazivaju oksidativni stres kroz indukciju reaktivnih supstanci tiobarbitonske aktivnosti (TBARS) i kroz redukciju aktivnosti antioksidantnih enzima (GST, SOD, CAT, GPx) i nivoa glutationa. Vrednosti markera enzimske aktivnosti jetre (AST, ALT, ALP, ACP, LDH i GGT), ukupnog bilirubina, uree, kreatinina i lipidnog profila su bili povećani, dok

\section{REFERENCES}

1. Wu J, Zheng Y, Song W, Luan J, Wen X, Wu Z, et al. In situ synthesis of silver-nanoparticles/bacterial cellulose composites for slow-released antimicrobial wound dressing. Carbohydrate Polymers. 2014; 102: 762-71.

2. Galdiero S, Falanga A, Vitiello M, Cantisani M, Marra V, Galdiero M. Silver nanoparticles as potential antiviral agents. Molecules. 2011; 16(10): 8894-918.

3. Monteiro DR, Silva S, Negri M, Gorup LF, de Camargo ER, Oliveira R, et al. Antifungal activity of silver nanoparticles in combination with nystatin and chlorhexidine digluconate against Candida albicans and Candida glabrata biofilms. Mycoses. 2013; 56(6): 672-80.

4. Mijnendonckx K, Leys N, Mahillon J, Silver S, Van Houdt R. Antimicrobial silver: uses, toxicity and potential for resistance. Biometals. 2013; 26(4): 609-21.

5. Chen X, Schluesener HJ.Nanosilver: a nanoproduct in medical application. Toxicol Lett. 2008; 176(1): 1-12.

6. Wei L, Lu J, Xu H, Patel A, Chen ZS, Chen G. Silver nanoparticles: synthesis, properties, and therapeutic applications. Drug Discovery Today. 2015; 20(5): 595-601.

7. Benn T, Cavanagh B, Hristovski K, Posner JD, Westerhoff $\mathrm{P}$. The release of nanosilver from consumer products used in the home. Journal of Environmental Quality. 2010; 39(6): 1875-82.

8. Massarsky A, Trudeau VL, Moon TW. Predicting the environmental impact of nanosilver. Environ Toxicol Pharmacol. 2014; 38(3): 861-73. su vrednosti hematoloških parametara bile snižene. Histopatološka ispitivanja indikovala su značajnu degeneraciju hepatocita, endotelijalnih ćelija bubrega, koje su sa svojom ulogom potvrdile hepatotoksičnost i nefrotoksičnost indukovane AgNPs. Prisustvo taninske kiseline u korelaciji sa AgNPs pokazalo se kao izuzetan napredak kod povrede tkiva jetre i bubrega. Protektivni efekat taninske kiseline u korelaciji sa toksičnošću AgNPs može biti objašnjen antioksidativnim karakteristikama, kao i osobenostima sličnih aktivnosti slobodnih radikala.

Ključne reči: srebrne nanočestice, taninska kiselina, anotoksikologija, hepatotoksičnost, povreda bubrega, reaktivne oksidativne čestice, DNK oksidacija, oksidativni stres, histopatološka arhitektura.

9. Ebabe Elle R, Gaillet S, Vidé J, Romain C, Lauret C, Rugani N, et al. Dietary exposure to silver nanoparticles in Sprague-Dawley rats: Effects on oxidative stress and inflammation. Food Chem Toxicol. 2013; 60: 297-301.

10. Schins RPF, Knaapen AM. Genotoxicity of poorly soluble particles. Inhalation Toxicology. 2007; 19(suppl 1): 189-98.

11. Hadrup N, Lam HR. Oral toxicity of silver ions, silver nanoparticles and colloidal silver- a review. Regul Toxicol Pharmacol. 2014; 68(1): 1-7.

12. McShan D, Ray PC, Yu H. Molecular toxicity mechanism of nanosilver. J Food Drug Anal. 2014; 22(1): 116-27.

13. Reidy B, Haase A, Luch A, Dawson KA, Lynch I. Mechanisms of silver nanoparticle release, transformation and toxicity: a critical review of current knowledge and recommendations for future studies and applications. Materials. 2013; 6(6): 2295-350.

14. Di Meo S, Reed TT, Venditti P, Victor MV. Harmful and Beneficial Role of ROS. Oxid Med Cell Longev. 2016; 2016.

15. Nićiforović N, Mihailović V, Mašković P, Solujić S, Stojković A, Muratspahić DP. Antioxidant activity of selected plant species; potential new sources of natural antioxidants. Food Chem Toxicol. 2010; 48(11): 3125-30.

16. Crozier A, Jaganath IB, Clifford MN. Dietary phenolics: Chemistry, bioavailability and effects on health. Nat Prod Rep. 2009; 26(8): 1001-43.

17. Wang YH, Wan ZL, Yang XQ, Wang JM, Guo J, Lin Y. Colloidal complexation of zein hydrolysate with tannic acid: 
Constructing peptides-based nanoemulsions for alga oil delivery. Food Hydrocolloids. 2016; 54(part A): 40-8.

18. Sahiner N, Sagbas S, Aktas N, Silan C. Inherently antioxidant and antimicrobial tannic acid release from poly (tannic acid) nanoparticles with controllable degradability. Colloid Surf B: Biointerfaces. 2016; 142: 334-43.

19. Tikoo K, Sane MS, Gupta C. Tannic acid ameliorates doxorubicin-induced cardiotoxicity and potentiates its anti-cancer activity: potential role of tannins in cancer chemotherapy. Toxicol Appl Pharmacol. 2011; 251(3): 191-200.

20. Halkes CJM, Van Dijk H, De Jaegere PT, Plokker HWM, van Der Helm Y, Erkelens DW, et al. Postprandial increase of complement component 3 in normolipidemic patients with coronary artery disease: effects of expanded-dose simvastatin. Arterioscler Thromb Vasc Biol. 2001; 21(9), 1526-30.

21. Xiao H, Liu B, Mo H, Liang G. Comparative evaluation of tannic acid inhibiting $\alpha$-glucosidase and trypsin. Food Res Int. 2015; 76(3): 605-10.

22. Fang N, Lee H, Sun C, Zhang X. Sub-diffraction-limited optical imaging with a silver superlens. Science. 2005; 308(5721): 534-7.

23. Sharma HS, Ali SF, Hussain SM, Schlager JJ, Sharma A. Influence of engineered nanoparticles from metals on the blood-brain barrier permeability, cerebral blood flow, brain edema and neurotoxicity. An experimental study in the rat and mice using biochemical and morphological approaches. J Nanosci Nanotechnol. 2009; 9(8): 5055-72.

24. Ahmad ST, Sultana S. Tannic acid mitigates cisplatin-induced nephrotoxicity in mice. Hum Exp Toxicol. 2012; 31(2): 145-56.

25. Tappel AL, Zalkin H. Inhibition of lipid peroxidation in mitochondria by vitamin $\mathrm{E}$. Archives of Biochemistry and Biophysics. 1959; 80(2): 333-6.

26. Mishra HP, Fridovich I. The role of superoxide anion in the autoxidation of epinephrine and a simple assay for superoxide dismutase. JBC. 1972; 247: 3170-5.

27. Chiu DTY, Stults FH, Tappel AL. Purification and properties of rat lung soluble glutathione peroxidase. Biochim Biophys Acta. 1976; 445(3): 558-66.

28. Habig WH, Pabst MJ, Jakoby WB. Glutathione S-transferases. The first enzymatic step in mercapturic acid formation. JBC. 1974; 249: 7130-9.

29. Luck H. Catalase. In: Bergmayer, M. V. (Ed.), Method of Enzymatic Analysis. Verlag Chemic. Academic Press, New. $1974 ; 885$.

30. Jollow DJ, Michell JR, Zampaglionic N, Gillete JR Bromoibenzene-induced Liver necrosis: Protective role of glutathione and evidence for 3,4-Bromobenzene oxide as hepatotoxic metabolite. Pharmacology. 1974; 11: 151-69.

31. Drury RA, Wallington EA, Carleton S. Histological Techniques, fifth ed., Oxford University Press, London, New York, Toronto. 1980; 241-2.

32. SAS, Statistical Analysis System. SAS Procedure Guide. Release 6.03 Edition. SAS Institute Inc., Cary, Nc, U.S.A 1998.

33. Duncan DB. Multiple range and multiple F tests. Biometrics. 1955; 11(1): 1-42.

34. Garcia T, Lafuente D, Blanco J, Sanchez DJ, Sirvent JJ, Domingo JL et al. Oral subchronic exposure to silver nanoparticles in rats. Food Chem Toxicol. 2016; 92: 177-87.
35. Kovvuru P, Mancilla PE, Shirode AB, Murray TM, Begley TJ, Reliene R. Oral ingestion of silver nanoparticles induces genomic instability and DNA damage in multiple tissues. Nanotoxicology. 2015; 9(2): 162-71.

36. Sarhan OMM, Hussein RM. Effects of intraperitoneally injected silvernanoparticles on histological structures and blood parameters in the albino rat. Int J Nanomedicine. 2014; 9: 1505-17.

37. Burrell RE. A scientific perspective on the use of topical silver preparations. Ostomy Wound Manage. 2003; 49: 19-24.

38. Toh HS, Batchelor-Mcauley C, Tschulik K, Compton RG. Chemical interactions between silver nanoparticles and thiols: a comparison of mercaptohexanol against cysteine. Science China Chemistry. 2014; 57(9): 1199-210.

39. Nemenqani D, El-Gharib O, Ahmed AM, Baiuomy AR. The protective effects of antioxidant (vitamin C) against hepatic oxidative damage induced by zinc oxide nanoparticals. IRJABS. 2015; 9(4): 502-9.

40. Wang J, Asbach C, Fissan H, Hülser T, Kuhlbusch TA, Thompson D, et al. How can nanobiotechnology oversight advance science and industry: examples from environmental, health, and safety studies of nanoparticles (nano-EHS). J Nanopart Res. 2011; 13(4): 1373-87.

41. He W, Zhou YT, Wamer WG, Boudreau MD, Yin JJ. Mechanisms of the $\mathrm{pH}$ dependent generation of hydroxyl radicals and oxygen induced by Ag nanoparticles. Biomaterials. 2012; 33(30): 7547-55.

42. Yang EJ, Kim S, Kim JS, Choi IH. Inflammasome formation and IL-1â release by human blood monocytes in response to silver nanoparticles. Biomaterials. 2012; 33(28): 6858-67.

43. Rahman F, Chowdhury S, Rahman MM, Ahmed D, Hossain A. Antimicrobial resistance pattern of gram-negative bacteria causing urinary tract infection. Stamford journal of pharmaceutical sciences. 2009; 2(1): 44-50.

44. Loeschner K, Hadrup N, Qvortrup K, Larsen A, Gao $\mathrm{X}$, Vogel U, et al. Distribution of silver in rats following 28 days of repeated oral exposure to silver nanoparticles or silver acetate. Particle Fibre Toxicology. 2011; 8(1): 18.

45. Casas-Grajales S, Muriel P. Antioxidants in liver health. World J Gastrointest Pharmacol Ther. 2015; 6(3): 59-72.

46. Skalska J, Dabrowska-Bouta B, Struzynska L. Oxidative stress in rat brain but not in liver following oral administration of a low dose of nanoparticulate silver. Food Chem Toxicol. 2016; 97: 307-15.

47. Yang ST, Wang X, Jia G, Gu Y, Wang T, Nie H, et al. Long-term accumulation and low toxicity of single-walled carbon nanotubes in intravenously exposed mice. Toxicol Lett. 2008; 181(3): 182-9.

48. Kim S, Choi JE, Choi J, Chung KH, Park K, Yi J, et al. Oxidative stress-dependent toxicity of silver nanoparticles in human hepatoma cells. Toxicology in vitro. 2009; 23(6): 1076-84.

49. Recknagel RO, Glende Jr EA, Dolak JA, Waller RL. Mechanisms of carbon tetrachloride toxicity. Pharmacol Ther. 1989; 43(1): 139-54.

50. Adeyemi OS, Whiteley CG. Interaction of nanoparticles with arginine kinase from Trypanosoma brucei: kinetic and mechanistic evaluation. International journal of biological macromolecules. 2013; 62: 450-6. 
51. Guyton AC, Hall JE. Dominant role of the kidney in long-term regulation of arterial pressure and in hypertension: the integrated system for pressure control. Guyton \& Hall: Textbook of Medical Physiology. 2000; 10: 195-209.

52. Venkatesan N, Punithavathi D, Arumugam V. Curcumin prevents adriamycin nephrotoxicity in rats. Br J Pharmacol. 2000; 129(2): 231-4.

53. Braydich-Stolle L, Hussain S, Schlager JJ, Hofmann MC. In vitro cytotoxicity of nanoparticles in mammalian germline stem cells. Toxicol Sci. 2005; 88(2): 412-9.

54. Albendea CD, Gómez-Trullén EM, Fuentes-Broto L, Miana-Mena FJ, Millán-Plano S, Reyes-Gonzales MC, et al. Melatonin reduces lipid and protein oxidative damage in synaptosomes due to aluminium. J Trace Elem Med Bio. 2007; 21(4): $261-8$

55. Ene-ojo AS, Chinedu EA, Yakasai FM. Toxic effects of sub-chronic administration of chloroform extract of Artemisia maciverae Linn on the kidney of Swiss albino rats. Int J Biochem Res Rev. 2013; 3(2): 119-28.

56. Sarkar D, Latif SA, Aich J, Uddin MM. Studies on serum Creatinine and Creatinine clearance in hypertensive patients. JBSP. 2006; 1: 19-26.

57. Adeyemi OS, Sulaiman FA. Biochemical and morphological changes in Trypanosoma brucei brucei-infected rats treated with homidium chloride and diminazene aceturate. Journal of basic and clinical physiology and pharmacology. 2012; 23(4): 179-83.

58. Adeyemi OS, Akanji MA. Psidium guajava leaf extract. Effects on rat serum homeostasis and tissue morphology. Comparative Clinical Pathology. 2010; 21(4): 401-7.

59. Naghsh N, Mashayekh AM, Khodadadi S. Effects of silver nanoparticle on lactate dehydrogenase activity and histological changes of heart tissue in male wistar rats. Journal of Fasa University of Medical Sciences. 2013; 2(4): 303-7.

60. Lovrić J, Bazzi HS, Cuie Y, Fortin GR, Winnik FM, Maysinger D. Differences in subcellular distribution and toxicity of green and red emitting CdTe quantum dots. J Mol Med. 2005; 83(5): 377-85.
61. Sharma V, Shukla RK, Saxena N, Parmar D, Das M, Dhawan A. DNA damaging potential of zinc oxide nanoparticles in human epidermal cells. Toxicol Lett. 2009; 185(3): 211-8.

62. Arora S, Jain J, Rajwade JM, Paknikar KM. Cellular responses induced by silver nanoparticles: in vitro studies. Toxicol Lett. 2008; 179(2): 93-100.

63. Tiwari R, Singh RD, Khan H, Gangopadhyay S, Mittal $\mathrm{S}$, Singh V, et al. Oral subchronic exposure to silver nanoparticles causes renal damage through apoptotic impairment and necrotic cell death. Nanotoxicology. 2017; 11(5): 671-86.

64. Meng J, Ji Y, Liu J, Cheng X, Guo H, Zhang W, et al. Using gold nanorods core/silver shell nanostructures as model material to probe biodistribution and toxic effects of silver nanoparticles in mice. Nanotoxicology. 2014; 8(6): 686-96.

65. Guo H, Zhang J, Boudreau M, Meng J, Yin JJ, Liu J, et al. Intravenous administration of silver nanoparticles causes organ toxicity through intracellular ROS-related loss of interendothelial junction. Particle Fibre Toxicology. 2016; 13(1): 21.

66. Vivarelli M, Massella L, Ruggiero B, Emma F. Minimal Change Disease. Clin J Am Soc Nephrol. 2016; 27: 1811-22.

67. Kroemer G, El-Deiry WS, Golstein P, Peter ME, Vaux D, Vandenabeele P, et al. Classification of cell death: recommendations of the Nomenclature Committee on Cell Death. Cell Death Differ. 2005; 12(suppl 2): 1463-7.

68. Li L, Wu H, Peijnenburg WJ, Van Gestel CA. Both released silver ions and particulate $\mathrm{Ag}$ contribute to the toxicity of AgNPs to earthworm Eisenia fetida. Nanotoxicology. 2015; 9(6): 792-801.

69. Uchiumi F, Sato T, Tanuma SI. Identification and characterization of a tannic acid-responsive negative regulatory element in the mouse mammary tumor virus promoter. J Biol Chem. 1998; 273(20): 12499-508.

70. Andrade RG, Dalvi LT, Silva JMC, Lopes GK, Alonso A, Hermes-Lima M. The antioxidant effect of tannic acid on the in vitro copper-mediated formation of free radicals. Arch Biochem Biophys. 2005; 437(1): 1-9.

\section{Correspondence to/Autor za korespondenciju}

\section{Dr. Israa F. Mosa}

Ph. D. in Biological Sciences, Department of Environmental Studies, Institute of Graduate Studies and Research, Alexandria University, Alexandria, Egypt

Teachingstaff at the Faculty of Education, Department of Natural Science,

Alexandria University, Egypt

Mobile: +20 - 01024680746

E-mail address: Israa_fat7y@yahoo.com 